\title{
Use of the emergency contraceptive pill in university students from Tunja, Boyacá
}

\section{Uso de la píldora anticonceptiva de emergencia en estudiantes universitarias de Tunja, Boyacá}

\author{
Juan Manuel Ospina Díaz ${ }^{1}{ }^{*}$, Carlos Alberto Niño Avendaño ${ }^{1,2}$, Ledmar Jovanny Vargas Rodríguez ${ }^{2}$ \\ ${ }^{1}$ Universidad Pedagógica y Tecnológica de Colombia, Tunja, Colombia \\ ${ }^{2}$ Universidad de Boyacá, Tunja, Colombia \\ * Dirigir correspondencia a: juan.ospina@uptc.edu.co
}

\begin{tabular}{lll}
\hline Article History \\
\hline Recibido: 23 & 01 & 20 \\
Aceptado:14 & 07 & 20 \\
Publicado:12 & 08 & 20 \\
\hline
\end{tabular}

DOI 10.17081/innosa.85

CCopyright 2020

Ospina-Días ${ }^{1}$ et al.

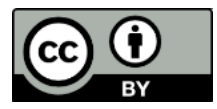

\section{ABSTRACT}

Background: The objective of this study was to asses frequency of employ, as well, as the level of knowledge of post-coital contraception in young female university students, living at the municipality of Tunja, Colombia

Methods: Descriptive, observational cross-sectional study. A sample of 615 students from two universities, public one and private the other, answered a survey about knowledge, sexual practices and the use of contraceptive methods, including the emergency contraceptive pill. Results: Mean age 21.18 years; Mean age of onset of sexuality 16.5 years; $59.7 \%$ had a stable partner; $69.6 \%$ answered that they had taken emergency contraception pill at least once in their life and $36.4 \%$ reported a frequency equal or greater than twice a year, while $17.5 \%$ considered it as a contraceptive method of habitual employment. Conclusions: Although the use of mechanical barrier methods as a method of contraception is not the objective of this study, we found that the condom is still the most commonly used contraceptive method by university students, but not used permanently or regularly. There is a high percentage of employment of emergency contraception pill, even with repetitive uses in short time periods. There is a high degree of conviction among young users about the contraceptive safety of the use of emergency contraception pill.

Keywords: Uncertainty; quality of life; caregivers; palliative care; nursing theory.

\section{RESUMEN}

Introducción: El objetivo de este estudio fue evaluar la frecuencia de empleo, así como el nivel de conocimiento sobre anticoncepción poscoital en jóvenes universitarias, residentes en el municipio de Tunja, Colombia Métodos: Estudio descriptivo, observacional, transversal. Una muestra de 615 estudiantes de dos universidades, una pública y otra privada, respondió una encuesta sobre conocimientos, prácticas sexuales y uso de métodos anticonceptivos, incluida la píldora anticonceptiva de emergencia. Resultados: Edad media 21,18 años; Edad media de inicio de la sexualidad 16,5 años; El 59,7\% tenía pareja estable; El 69,6\% respondió que había tomado la píldora anticonceptiva de emergencia al menos una vez en la vida y el 36,4\% refirió una frecuencia igual o superior a dos veces al año, mientras que el 17,5\% lo consideró como un método anticonceptivo de empleo habitual. Conclusiones: Aunque el uso de métodos de barrera mecánica como método anticonceptivo no es el objetivo de este estudio, encontramos que el condón sigue siendo el método anticonceptivo más utilizado por los estudiantes universitarios, pero no se utiliza de forma permanente ni habitual. Existe un alto porcentaje de empleo de la píldora anticonceptiva de emergencia, incluso con usos repetitivos en períodos cortos de tiempo. Existe un alto grado de convicción entre las usuarias jóvenes sobre la seguridad anticonceptiva del uso de la píldora anticonceptiva de emergencia.

Palabras Claves: Incertidumbre; calidad de vida; cuidadores; cuidados paliativos; teoría de enfermería.

Cómo citar: Ospina J, Niño C, Vargas L. Uso de la píldora anticonceptiva de emergencia en estudiantes universitarias de Tunja. Ciencia e Innovación en Salud. 2020. e85: 257-265. DOI 10.17081/innosa.85 


\section{INTRODUCTION}

Among Latin American adolescents and young people, it is very common for unprotected sex to occur; One of the immediate consequences are unwanted pregnancies, which in many circumstances significantly affect the future of young people, being cause, in many cases, dropout and health damages. It is estimated that in the period 2010-2014, about twenty-five million abortions were performed, a third of them clandestine (1), in poor technical and hygienic conditions and in countries with low development. Emergency contraception (EC), also called the morning after pill, is an acceptable efficiency resource to avoid unwanted pregnancy, in particular cases such as violations or mishaps leading to the absence of contraceptive protection. The most common employment recommendation is: women must start taking the emergency contraceptive pills as soon as possible, after a sexual intercourse without adequate protection, whatever the circumstances and the time of the current menstrual period; contraception should be effective even until five days after intercourse, although the effectiveness of the method is inversely related to the time elapsed, so that the sooner it is, the greater the likelihood to preventing a pregnancy (2).

Despite the promotion of the use of emergency contraception pill as an alternative, there is still no clarity if in the promotion and prevention processes, focused on sexual and reproductive health, indications say clearly enough about the characteristic of being an exceptional method (3) and that their employment should not become a sequential or "routine" method of contraception, which is apparently true, particularly among adolescent girls and young students.

In Colombia, four emergency contraception schemes are recognized at the Ministry of Health:

1. Yuzpe or combined regimen (four pills containing Etinil Estradiol and Levonorgestrel), 2 tablets or pills are taken until 72 hours after sexual intercourse, followed by two more tablets or pills, 12 more hours late;

2. Only progestin: pills containing levonorgestrel (two tablets or pills with $750 \mu \mathrm{g}$ ). The tablets or pills taken within 72 hours after unprotected sexual intercourse;

3. Intrauterine device (IUD) or Copper T, It can be used until the fifth day after risky sexual intercourse;

4. Ulipristal acetate, which can be taken until the fifth day (120 hours) after risky sexual intercourse, prevents pregnancy in $98 \%$ of cases (4), its use is not recommended in women less than 18 years age ( $\underline{5})$.

The available evidence suggests that currently, available information about contraceptive methods, addressed to adolescents and young people in Latin America is relatively scarce and not always well addressed, because health services do not adapt their information strategies to Youth needs and expectations (므). In these circumstances, it is not uncommon to consider that sexual and reproductive health interventions referred to adolescents and young people in general 
are still directed by rigid regulations, which lead to sexual practices that occur in many cases, under clandestine conditions and without adequate protection methods $(\underline{7}, \underline{8})$.

In terms of strategies aimed to optimize the rational and measured use of emergency contraception pill, it is important to consider the need for mass education strategies, aimed at widely disseminating the benefits derived from the opportune and correct use of emergency contraception pills; in the same way, the best methods to train dependents of pharmacies and counseling services in sexual and reproductive health to encourage young women to use routine contraceptive methods such as condoms, and to be able to use contraceptive use of emergency method, only immediately after unprotected sex, and only as an exceptional employment alternative.

This study lead to estimate the frequency of use as well as, the level of knowledge of postintercourse contraception pills, by young female university students, living in the municipality of Tunja, Colombia, with the intention of collaborating with the institutional health authorities in the orientation and design of public health policies aimed at optimizing the rational use of this contraceptive technique as well as reducing the possible risks arising from excessive or inappropriate use.

\section{METHODS}

A descriptive, observational cross-sectional study was designed. For this purpose, the young female university students of two institutions of higher education, public one and private the other, were considered as population. Sample size was estimated since a prevalence of reported emergency contraceptive use in a Latin American country of 16\% (ㅁ), with a significance of 0.025 and $95 \%$ reliability, in 615 participants.

To collect the data, a datasheet was structured including social and demographic questions, knowledge about contraception and emergency contraception, as well as frequency of use of different contraceptive methods, which was revised and approved by a group of research experts. Data collection was carried out by inserting the questionnaire in the Google Docs application, together with an informed consent text. An invitation to participate in the study, together with the corresponding link of the survey was sent to the active institutional email of the students enrolled in the faculties of the corresponding universities; to proceed to answer the questionnaire, it was necessary previously sign agree the corresponding informed consent. When a total of 615 respondents were reached, data capture was ended.

Subsequently, an Excel database was assembled, which was analyzed using the Epi-Info 7 statistical program. In the cases of qualitative variables, a frequency analysis and the corresponding 95\% confidence intervals were performed; when there were quantitative variables, measures of central tendency and dispersion were estimated. When it was considered, to make correlations or comparison between variables, bivariate analysis was carried out, with the corresponding Chi-square tests and significance value of $p<0.05$. 
The designed protocol was submitted for assessing and approval of the corresponding institutional Bioethics Committee, it was considered as a risk-free study, in accordance with the guidelines of Resolution No. 8430 of 1993, issued by the Colombian Ministry of Health, which establishes the standards scientific, technical and administrative for health research. Participation was voluntary and subsequent to the signing of informed consent; the research group was committed at all moments to preserve bioethical principles of confidentiality and beneficence, guaranteeing the absolute privacy of the participants (10).

\section{RESULTADOS}

Characterization of the sample. 615 students, aged between 18 and 40 answered the questionnaire; the mean age was 21.18 years $(S D=4.19)$, the median was 20 years. $72.9 \%$ ( $n$ $=444$ ) was studying the basic level of his program; $89 \%$ proceeding from urban areas; $90.0 \%$ single and $59.7 \%$ said they had a stable couple. The average age of onset of sexual intercourses was 16.65 years, although around $27 \%$ had their first relationship with penetration, before they turned 16 , and only $10 \%$ of those surveyed, with an average age of 18 , said have still not had sex; Table 1 shows the frequency of use of some contraceptive methods:

Table 1. Frequency of use of some contraceptive methods. University students from Tunja, Colombia. 2017.

\begin{tabular}{|l|c|c|}
\hline \multicolumn{1}{|c|}{ METHOD } & PEOPLE THAT HAS USED IT & PERCENTAGE \\
\hline BARRIER (CONDOM) & 518 & $84,1 \%$ \\
\hline SECUENTIAL HORMONAL METHODS & 408 & $66,2 \%$ \\
\hline NATURAL METHODS (OGINO, RITHM & 220 & $35,7 \%$ \\
\hline EMERGENCY CONTRACEPTIVE PILLS & 429 & $69,6 \%$ \\
\hline
\end{tabular}

Source: own data

Among those who said they had used emergency contraceptive pill methods, it was found that the average age at which they began using these methods was 17.4 years $(S D=2.5$; median 17 , mode 17$) ; 36.34 \%(n=161)$ showed a frequency of emergency contraception pills employment greater than 1 time each year. When were asked about the frequency of emergency contraception pills in the last six months, a prevalence of $38.03 \%(n=208)$ was found, while $16.5 \%(n=102)$ had used it in two or more opportunities. A similar percentage of participants, $17.7 \%(n=109)$ stated that they considered emergency contraception pill as a usual contraceptive method. $29.87 \%(n=184)$ consider that the method of emergency contraception pill completely eliminates the risk of pregnancy. 
Table 2. Main symptoms referred after the employment of the emergency contraception pills. University students from Tunja, Colombia. 2017.

\begin{tabular}{|l|c|c|}
\hline LINKED SYMPTOMS & FREQUENCY $(\mathbf{n}=\mathbf{4 2 9})$ & PERCENTAGE \\
\hline Nausea / Vomiting & 96 & $22,30 \%$ \\
\hline Headache & 92 & $21,40 \%$ \\
\hline Colic & 43 & $10,00 \%$ \\
\hline Mood changes & 14 & $3,26 \%$ \\
\hline Bleeding & 15 & $3,50 \%$ \\
\hline
\end{tabular}

Source: own data

When the women were questioned that, When an unprotected sexual relationship occurred, it would be adequate to seek the advice of a health agent, $84.9 \%(n=523)$ answered affirmatively, while $80.5 \% \quad(n=496)$ considers that, if a woman is using with hormonal contraceptive methods, and has forgotten or missed taking them, emergency contraception pill would be indicated as the best method of protection.

\section{DISCUSSION}

It was found that in this population group in the city of Tunja, the age of 16.5 years for start sexual activities has decreased, compared to an study carried out in 2007 with university students from this city, who reported an age of 17.5 years (11), although it is a record of age less than reported in other regions of the country (12). In this regard, it should be noted that although the age to onset of sexual relations seems to be a non-easily modifiable factor, the degree of knowledge about fertility and contraception of young women and adolescents constitutes a serious obstacle to the development of sexuality in safe conditions or with low risk of unwanted events such as pregnancy or venereal diseases (13). Moreover, to this circumstance is added the fact of the spontaneity, instability and short duration of the affective or sex intercourses established by young women and adolescents that lead to higher rates of contraception failure, discontinuity, omissions and low adherence to systematic employment of contraceptive methods such as condom or anovulatory use in all your sexual interactions (1416).

Then, it should be considered, which social sector has the responsibility of designing and implementing communication and health education strategies that allow adequate appropriation, as well as a solid motivation in young people and adolescents, so that in the case of assuming sexual practices, they can consider beforehand the risks and the appropriate protection measures for the erotic experience. In various inquiries it has been found that the main source that provides knowledge about sexuality is made up of secondary school teachers (17), it is also reported in other sources that the best alternative considered by young women to obtain clear and reliable information on health aspects sexual and reproductive are health 
professionals (18); This is how in this work, almost $85 \%$ of the participants also expressed their interest in being advised mainly by health personnel. It would then be convenient for the governing authorities of the health and education sectors to propose efforts and resources aimed at focusing the emphasis on knowledge of sexual and reproductive health in the universities that offer bachelor's degrees in education, while at the same time Faculties of health sciences will be reinforced in the areas of primary care and preventive medicine the

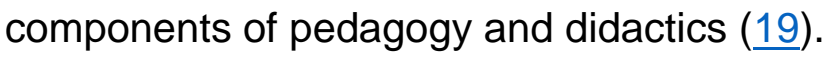

In relation to what has to do with the research that is being carried out on the way in which young women and adolescents assume the use of emergency contraception pill, it is clear that the interest is more focused on the frequency of use of the method, and on minor degree about the level of knowledge that users have about the correct way of employment, the security it offers and the possible risks and side effects (므).

Another worrying aspect regarding the level of knowledge about the use of emergency contraception pill, has to do with the conviction reflected in the response of almost a fifth of the respondents that considers this practice analogous to a contraceptive sequential method, a circumstance that as It has been seen, can lead to significant changes in the physiology of the menstrual cycle while negatively modifying the rate of effectiveness as a contraceptive technique (21). So far there are no known reports of adverse events associated with emergency contraception, nor increased cardiovascular risk, it is recognized that there may be intermenstrual bleeding and increased period duration, as well as endometrial modifications, which would show as significant modifications of the hormonal rhythm (22). The frequency of use, in the last 6 months on two or more occasions of emergency contraceptive pill therapy is consistent with that reported in an advanced study in a Latin American country, with a sample

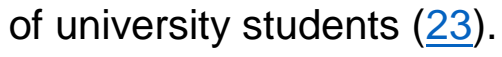

Although the use of mechanical barrier methods as a method of contraception is not the objective of this study, we found that the condom continues being the contraceptive method with the highest rate of use, followed by hormonal compounds, a finding that coincides with that reported in similar studies ( $\underline{9})$. Regarding the frequency of use of emergency contraceptive pill methods, this shows a high frequency, increased by an exaggeratedly safe vision of this method by young adolescents, a circumstance that shows a wide informative media display of the method, at the institutional level and also by private ones, leading to finding that in Colombia, $66 \%$ of women have received some information on emergency contraception pill (24). The present report also coincides with the evidence regarding a determining condition for the use of emergency contraception pill, which is the level of education of the women surveyed, since it is clear that greater schooling increases the employment rate of the method.

However, it is clear that the dissemination that health organizations extend about convenience of post-intercourse contraception, leads us to believe that there is no emphasis about the fact that this is a measure of protection that should be assumed as exceptional one, that is, as a consequence of unforeseen circumstances, given the existence of other contraceptive alternatives that are safer and less risky. In this way it is important to keep in mind that an exaggeratedly frequent use in short periods, can lead to health complications and a modified negatively contraceptive efficacy ( $\underline{25})$. 
From health field, it is proposed assertively that in the primary care and preventive medicine services, education components designed for the group of young women and adolescents are builder and structured, doing emphasis on functionality of the body and the psyche in the spheres of sexuality is first and foremost, as well as the ways of approaching it in a conscious and responsible way; more detailed, emphasis is placed on a methodology called pedagogical mediation, an intervention scheme in which not only the appropriation of knowledge is sought by the recipient, but also full awareness towards its application in real-life circumstances (26).

Moreover, it is necessary that the research centers on the biology of reproduction, seek to deepen instrumental studies that allow optimizing more effective and long-term contraception mechanisms with minimum side effects, in order to facilitate young people, an extensive exercise of eroticism, without fear to unwanted or unplanned pregnancy.

In concern with the scope and limitations of this study, although definitive conclusions cannot be made due to the sampling that turns out to be sequential and non-probabilistic, if it is important to consider that from the exploratory findings described door is opened, to design more elaborate studies. It is also important to consider that for university institutions, a deep revision of their strategies of well-being and support to students is proposed, about the need to formulate appropriate and effective sexual and reproductive health education strategies, aimed at the entire academic community.

Particular interest should be given to the prevention of adverse or unwanted events in terms of sexual and reproductive health, facilitating that young students and adolescents can freely and safely opt for sexuality that contributes to their personal fulfillment, eliminating possible risks.

\section{CONCLUSIONS}

A high rate of repetitive and routine use of emergency contraception pill is found that, for about $20 \%$ of users tends to seeing it as a sequential contraceptive method, because poor knowledge of the efficacy and safety of the method in comparison with other more effectives and less risky.

Author Contributions: Conceptualization, J.M.O, C.A.N and L.J.V; Methodology, J.M.O, C.A.N and L.J.V.; Software, J.M.O.; Validation, J.M.O, C.A.N.; formal analysis, J.M.O, C.A.N; research, J.M.O, C.A.N and L.J.V.; resources, NA.; data healing, NA.; writing: preparation of original draft, X.X.; writing: review and editing, J.M.O, C.A.N.; visualization, J.M.O, C.A.N; supervision, J.M.O.; project management, J.M.O.; fund acquisition, NA. All authors have read and accepted the published version of the manuscript.

Founds: This investigation did not require external financial resources

Conflict of interest: The authors declare that they have no conflict of interest 


\section{REFERENCES}

1. Organización Mundial de la Salud. Comunicado de prensa, 28 de septiembre de 2017. Ginebra. Disponible en: https://www.who.int/es/news-room/detail/28-09-2017 worldwide-an-estimated-25million-unsafe-abortions-occur-each-year

2. Jiménez-Iglesias A, Moreno C, García I, Rivero F. Prevalence of emergency contraceptive pill use among Spanish adolescents girls and their family and psychological profiles. BMC Women's Health (2018) 18:67 https://doi.org/10.1186/s12905-018-0560-x

3. Eun SL, Chong Al, Jee HL, Bo RP, Imsoon L. The attitudes of Korean physicians toward emergency contraceptive pills: regarding women's access and rescheduling Obstet Gynecol Sci 2019;62(3):173178. http://dx.doi.org/10.5468/ogs.2019.62.3.173

4. Lee JK, Schwarz EB. The safety of available and emerging options for emergency contraception. Expert Opin Drug Saf 2017; 16:1163-71. DOI: 10.1080/14740338.2017.1354985

5. Colombia. Ministerio de Salud. ABC sobre anticoncepción de emergencia, 2016. Disponible en: https://www.minsalud.gov.co/sites/rid/Paginas/freesearchresults.aspx?k=\&k=anticoncepci\%C3\%B3n\% 20de\%20emergencia

6. Ditmars L, Rafie S, Kashou G, Cleland K, Bayer L, Wilkinson TA. Emergency Contraception Counseling in California Community Pharmacies: A Mystery Caller Study. Pharmacy (Basel). 2019 Apr 23;7(2). pii: E38. DOI: 10.3390/pharmacy7020038

7. Covarrubias ES, Ramírez R, Verde EE, Rivas JG, Rivero LF. Utilización de métodos anticonceptivos en estudiantes de enfermería. Investig Enferm. Imagen Desarr. 2016;18(2): 31-43. DOI 10.11144/ Javeriana.ie18-1.umae

8. Sili PS, Pelaez J. Nivel de conocimientos sobre anticoncepción hormonal de emergencia en estudiantes de medicina. Revista Cubana de Obstetricia y Ginecología. 2018;44(2). Disponible: http://scielo.sld.cu/pdf/gin/v44n2/gin05218.pdf (Consulta: 08-09-2019)

9. Acevedo-Osorio GO, Ramírez García N, Cardona-Osorio JD, Oliveros-Ruiz CA. Conocimiento y uso de método anticonceptivo de emergencia en estudiantes universitarios, Pereira, Colombia 2017. Univ. Salud. 2019; 21(2):159-165. DOI: http://dx.doi.org/10.22267/rus.192102.150

10. Asociación Médica Mundial (AMM). Declaración de Helsinki de la AMM - Principios éticos para las investigaciones médicas con seres humanos. $64^{\circ}$ Asamblea General. Ratificada en Fortaleza, Brasil 2013. Disponible en: http://www.isciii.es/ISCIII/es/contenidos/fd-investigacion/fd-evaluacion/fdevaluacion-etica-investigacion/Declaracion-Helsinki-2013-Esp.pdf

11. Ospina JM, Manrique FG. Prácticas y comportamientos sexuales en estudiantes universitarios. Av. Enferm. 2007; XXV (2): 101-111. Disponible en: https://revistas.unal.edu.co/index.php/avenferm/article/view/12814/13633

12. Uribe Rodríguez, A. F., Castellanos Barreto, J. y Cabán Huertas, M. (2016). Conductas sexuales de riesgo y comunicación sobre sexualidad entre padres e hijos universitarios Revista de Psicología $\begin{array}{lllll}\text { Universidad de } & \text { 27-48. } & \text { Disponible en }\end{array}$ https://dialnet.unirioja.es/servlet/articulo?codigo $=6059401$

13. Herrera IA, Reyes JF, Rojas KP, Tipán ML, Torres CA, Vallejo LM, et al. Salud sexual reproductiva en estudiantes universitarios: conocimientos y prácticas. Rev. cienc. cuidad. 2018; 15(1):58-70. DOI: 10.1016/i.contraception.2006.02.009 
14. Morín-Juárez A, Treviño-Alanís M, Rivera-Silva G. Estudiantes universitarias embarazadas. Rev Med Inst Mex Seguro Soc. 2019;57(1):4-5. Disponible en: https://www.medigraphic.com/cgibin/new/resumen.cgi?IDARTICULO=86953

15. Reina JA, Criollo CA, Fernández K. El apoyo social en la maternidad indeseada de estudiantes universitarias Ecuatorianas: Análisis desde la perspectiva de género. Prospectiva Revista de Trabajo Social e intervención social 2019; (27): 107-137. DOl: 10.25100/prts.v0i27.6745

16. Martínez GI. Bauman: sobre la fragilidad de los vínculos humanos. Universitaria 2018; 1(4): 1416. Disponible en: https://revistauniversitaria.uaemex.mx/article/view/9853 (Consulta: 17 sep. 2019)

17. Hernández Y, Peláez FE, Serrano AC, Barros SM, Cedillo ML, Vanegas OS. Creencias, actitudes y prácticas en sexualidad en estudiantes de psicología clínica de la Universidad Católica de Cuenca. Revista electrónica de psicología Iztacala 2017; 20(3): 307-336. (Consulta: 16-09-2019) Disponible en: http://www.iztacala.unam.mx/carreras/psicologia/psiclin/vol20num3 monografico/Vol20No3Art17.pdf

18. Guerrero-Ortiz HA, Benavides-Espinoza M, Guzman-Barrantes EK, Meneses-Prieto CC. Nivel de conocimientos, actitudes y prácticas sobre métodos anticonceptivos en estudiantes de medicina humana 2017. Rev Médica Panacea [Internet]. 2017; 6(3):116-22. DOI: 10.35563/rmp.v6i3.46

19. Meza, V. Mediación pedagógica en salud sexual y reproductiva, derechos sexuales y reproductivos dirigida a adolescentes. Rev. Enfermería Actual en Costa Rica 2016; 31: 1-16. DOl: 10.15517/revenf.v0i31.24755

20. Sames C, Vázquez S, Discacciati V. Conocimiento, utilización y obtención de la anticoncepción de emergencia por adolecentes en Rauch, provincia de Buenos Aires. Rev Argent Salud Pública. 2012; 3(11):16-22. http://rasp.msal.gov.ar/rasp/articulos/volumen11/articulo conocimiento.pdf

21. Cárdenas-García LJ, Sánchez-Zamora ME, Ramírez-de la Roche OF, Robledo-Domínguez A. Uso de la anticoncepción de emergencia en un grupo de estudiantes universitarias. Aten Fam. 2014; 21(3):90-93. DOl: 10.1016/S1405-8871(16)30025-6

22. Gainer E, Kenfack B, Mboudou E, Sana A, Bouyer J. Menstrual bleeding patterns following levonorgestrel emergency contraception. Contraception 2006; 74:118-24. DOl: 10.1016/i.contraception.2006.02.009

23. Palermo T, Bleck J, Westley E. Conocimiento y uso de la anticoncepción de emergencia: un análisis multipais. Perspectivas Internacionales en Salud Sexual y Reproductiva, número especial de 2015, pp.
$1-8$,
doi:
10.1363/SP00115
Disponible:

https://www.guttmacher.org/sites/default/files/article files/4100115s.pdf

24. Sánchez-Meneses MC, Dávila-Mendoza R, Ponce-Rosas ER. Conocimiento y uso de métodos anticonceptivos en adolescentes de un centro de salud. Aten Fam [Internet]. 2015;22(2):35-8. Disponible en: https://www.medigraphic.com/pdfs/atefam/af-2015/af152b.pdf

25. González E, Molina T, Lutges C. Características de la educación sexual recibida y su asociación con la edad de inicio sexual y uso de anticonceptivos en adolescentes chilenas sexualmente activas. Rev Chil Obstet Ginecol 2015; 80(1): 24 - 32. DOI: 10.4067/S0717-75262015000100004

26. Rojas R, de Castro F, Villalobos A, Allen-Leigh B, Romero M, Braverman-Bronstein A, Uribe P. Educación sexual integral: cobertura, homogeneidad, integralidad y continuidad en escuelas de México. Salud Publica Mex 2017;59:19-27. DOI: 10.21149/8411 